\title{
Paleoenviromental Investigations, chemical analysis and characterization of underwater strata of Marigondon Cave
}

\author{
Carmen R. Rocha *, R. R. Chianelli *, J. Peterson**, Andrea Jalandoni*** \\ Ma, Lin**** \\ *Materials Research and Technology Institute, University of Texas at El Paso, $500 \mathrm{~W}$. \\ University Ave, El Paso, Texas 79968 \\ ** Director-MARC University of Guam, UOG Station, Mangilao, Guam 96923 \\ ***University of the Philippines at Diliman Archaeological Studies Program \\ ****Assistant Professor, University of Texas at El Paso, Department of Geological Sciences, \\ 500 W. University Ave, El Paso, Texas 79968
}

\begin{abstract}
The submarine Maringondon Cave (MC) is not only one of the most spectacular diving caves but also an unstudied, submerged rock-shelter with potential for intact stratigraphy. Archeological expeditions to the Maringondon Cave yield two rock samples Travertine and Sclerosponge, which provided evidence to understand the external and environmental conditions to which the cave might have been exposed to. Analytical methodologies such as IR spectroscopy, X-ray diffraction, Optical Microscopy and SEM/EDX analyses were carried out to determine the chemical composition of two rock samples, and their crystal structures. The study focus is to determine the link between the cave's underwater conditions and the samples studied. Results concluded that the two samples were composed mainly of the two calcium carbonate polymorphs calcite and aragonite; however, the sclerosponges contained a low percentage of Mg-calcite. Marigondon Cave would have been above water and favorable for Pleistocene fauna as well as possibly human settlement. This suggests that MC provides prospects for discovery of fossil assemblages that may be preserved in terrestrial deposits in the caves
\end{abstract}




\section{Introduction}

The Maringondon Cave located on Barangay Maringondon, on the south-east coast of Mactan Island, is best known as one of the most famous diving spots in Cebu City, Philippines, especially for advanced divers, but little is known about its potential for archeological and paleoenviromental contributions. The cave holds unique historical characteristics to identify paleoenviromental remains and imperative in comprehending patterns of human settlement and diaspora (1). .It is assumed that many coastal landscapes exposed to a lower sea level provide refuge for plants, land mammals and humans (2). Caves and rock shelters have long attracted human habitation as evidenced by archaeological and paleoenviromental remains at previously unexcavated shelters. These findings make underwater cave archeology a rapidly expanding field of investigation. It has also been established that the MC would have been above sea level during the last glacial periods of 22,000 a BP and 38,000 a BP which are congruent with the two periods in which the Tabon Cave in Palawan Island, Philippines and the Callao Cave in Northern Luzo were occupied, suggesting that the MC could have been inhabited during one or both glacial periods (3) .

The MC has been classified as a flank margin cave, which is a cave developed in carbonate islands at the edge of the fresh-water lens during sea-level high stands. The mixing of fresh water and saline water, bacterial oxidation and reduction of organic matter are the chemical processes that drive the origin of the flank margin caves (4)

$\mathrm{MC}$ is one of the 13 coral reef platforms that formed underwater as early as 120,000 years ago during lower sea-level still-stands; the cave formed itself during the subaerial emergence of the platform and then was alternatively submerged again in the last 10,000 years(3). 
The now 30 meter $(\mathrm{m})$ below sea level MC is being studied by the University of Guam in collaboration with The University of Texas at El Paso. A team of divers led by the Underwater Archaeology Section of the Archaeology Division of the National Museum of the Philippines conducted investigations in the marine Marigondon Cave off Mactan Island, Cebu. Two areas were excavated to examine the sediments and the stratigraphy of the cave deposits. Two specimens were recovered: Travertine and Sclerosponges. During the investigations, it was confirmed that the floor of the cave is amenable to removal and that the cave would have been a highly attractive locale for settlement during its period of emergence above sea level (3).

Travertine rock was found in the very rear of the Marigondon cave; it formed a mantle over coral reef fossils from the old coral reef platform that the cave originally formed while above water in the interior of the cave and subsequent to the dissolution of the carbonate reef platform during the formation of the flank margin cave (3) .Travertine is a product of the earth's water and carbon cycles. The rate of carbonate precipitation involved in the formation of travertine is greatly controlled by environmental conditions such as water chemistry, substrate morphology and biomineralization processes (5)

Calcium carbonate associated with travertine can be derived from cyanobacteria photosynthesis in freshwater environments. Many solid mineral phases are formed during the bacterial processes in which mineral deposition occurs over a geological timescale. The mineral form of calcium carbonate deposited being calcite or aragonite (6) . These environmental, biological and geological conditions make travertine ideal sediment for the purposes of this study

The second sediment, sclerosponges were on the ceiling near the front of the $\mathrm{MC}$, these sediments were formed when sea level was below the mouth of the cave and are formed from a 
solid mass of calcareous material. The calcium carbonate contained in the skeleton of these rocks is in the form of aragonite, calcite and Mg-calcite. The activities of microbes (and other organisms) in rock and minerals are dependent on precipitation and deposition of crystalline material (6) .

Organisms attach to the substrates of these rocks, making the "skeleton" of the sclerosponge rock organize into tubes and calyces. Present-day sclerosponges suggest as a possible relicts or "living fossils" and some scientist considers modern sclerosponges as potential sediment to study especially because of their great morphologic similarity to extinct stromatoporoid, which were important reef organism formers in the Paleozoic and Mesozoic eras (7). Their skeleton consists either of overlapping dome-shaped, convex-inwards plates of concentric laminar structure with various supports or pillars (8).

It is thought that sclerosponge rocks can provide clues regarding historical water temperatures and salinities, remarkably the chemical composition of their skeletons is directed by the surrounding water composition at the time that they lived. They also give information about the sea level rise related to rapid temperature change, which is of significant importance to this study. (9) .

Sediment records are the primary source for investigating sea level and climate information on coastal environments. Lowered sea levels have been typical for most of the Pleistocene epoch, and periods of high sea level are too short-lived to provide coastal records that will help to understand human settlement. Changing sea levels and climate significantly impacted migration throughout the islands in Cebu Philippines (10) . The strata collected from Marigondon cave not only adds to what is already know from on land sites, but will likely produce qualitatively different evidence for coastal adaptations and landscapes that have no analogue to present day coastlines. Sedimentary 
studies are important in providing an understanding into coastal and archeological landscapes formed during periods of lowered sea level. The global climate information and data that was collected from seafloor cores and glaciers shows that over the past 100,000 years, considerable extremes of sea levels have existed. The comparison can be made with today's elevation as during the last complete glacial period; the sea level reached over 100 meters (3).

\section{Area of Study}

The underwater Marigondon Cave is located in Mactan Island, Cebu City, Cebu, Philippines Figure 1 Silt removal and excavation were performed in the underwater Marigondon Cave to look for the presence of archeological deposits; the discovery of archeological deposits represents an important issue for the Philippines regional archaeology. The archeologists at the National Museum were responsible for creating a detailed map of the cave, the first of its kind. (3) . In this descriptive and detailed map, it is clear that the cave is more complex than was previously known. It is known from the mappings that the cave rises from 40 meters at the front of the mouth to the rear, 60 meters into the shore and 28 meters below the surface. Divers used this information in order to select their areas for excavation (typically two), which was used to examine sediments and the stratigraphy of the cave deposits. They also collected sediments in bulk that were transported to the surface with lift bags. The detailed process shows how remarkably easy it is to excavate on land, compared to the work required for an underwater project (11) . 


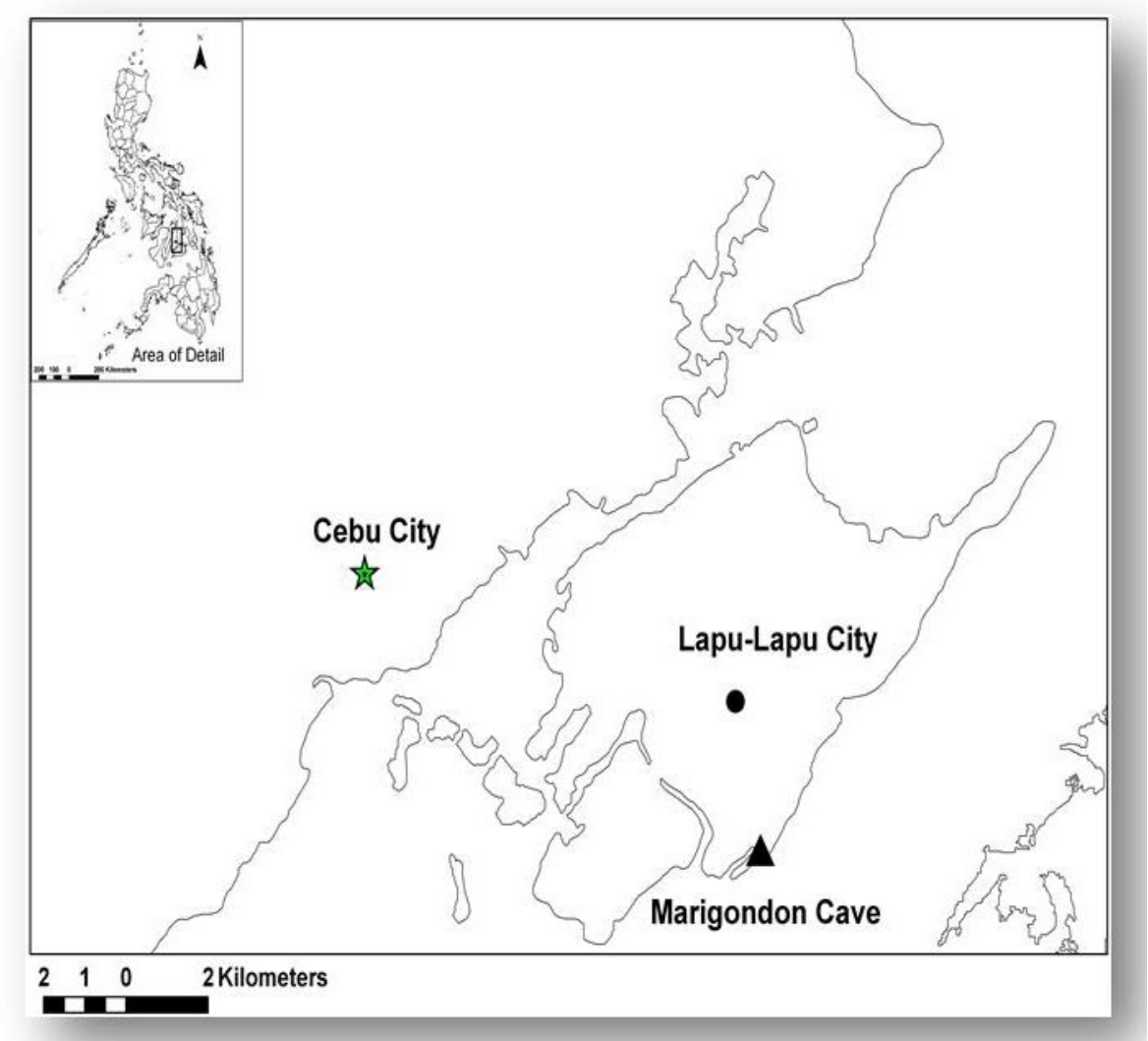

Figure 1 Location of Marigondon Cave (Source Peterson, 2013)

\section{Experimental Procedure}

Both samples were ground into a powder composition using a mortar for facile characterization. The morphology of the rocks was analyzed by a scanning electron microscope (SEM) (Hitachi S4800), Japan at 20 and $10 \mathrm{kV}$. The powders were analyzed by powder X-ray diffraction (XRD), (Bruker D8 Discover), at room temperature using $\mathrm{Cu} \mathrm{K \alpha}$ radiation, scanning $2 \theta$ angles ranging from 5 to 80 . One thin section of each sample was made to do the petrographic analyses using Optical microscopy(Olympus Optical BX60 Model U-L-H100HGAPO) at different magnifications from $5 \mathrm{x} / 0.5 \mathrm{BD}, 10 \mathrm{x} / 0.30 \mathrm{BD}, 20 \mathrm{x} / 0.40 \mathrm{BD}, 50 \mathrm{x} / 0.50 \mathrm{BD}$ and $100 \mathrm{x} / 1.30$ oil, employing eye pieces SWH10x-H/26.5 in transmitted and reflective light to analyze both samples, hand specimens were 
used to do observations using lower magnifications with the stereoscopic microscope (Olympus SZX12) using PLFL1.6XPF objective with eye pieces WHS10x-H/22 to allow the identification of the principal features that characterizes the stone alteration. Fourier transform infrared (FTIR) method was developed for the analysis of the rocks in Nexus 470 FT-IR Thermo Nicolet spectrometer in the range of $4000-400 \mathrm{~cm}^{-1}$. A powder mixture made of travertine/sclerosponges and potassium bromide was used for the IR analyses. The powder mixture was placed in a mechanical press to form a translucent pellet to be placed in the spectrometer; simulation of the XRD patterns were performed in CERIUS 2 software to compare the patterns of the samples with an established pattern of the different crystal structures contained in the rocks.

\section{Results and discussions}

\section{Powder X-ray diffraction (XRD)}

Calcite and dolomite are by far the most common minerals found in ancient carbonate rocks, the elemental composition of calcite and aragonite is determined by biochemical and physicalchemical processes (12) . Chemical composition of the carbonate rocks are affected by different paleoenviromental indicators such as temperature, salinity variations of the seawater, carbon cycling of ancient ocean-atmosphere systems and document global fluctuation in the climate.

The composition of carbonate sediments was studied using XRD analyses in a Bruker Discover $X S X$-D $8 X R D$ system employing a copper target to produce characteristic $\mathrm{x}$-ray wavelength of $0.154 \mathrm{~nm}$, which is commonly used to determine chemical composition of carbonate rocks (12) . The diffraction values characteristic for each Bragg reflections were compared with established patterns of the EVA software. The XRD patterns of travertine and sclerosponge are shown respectively in Figure2 and Figure 3. Both spectra reflex the presence of the minerals calcite and 
aragonite, which characteristic diffraction peaks are listed in Table 1. Also sclerosponge sample present the mineral dolomite which contains magnesium carbonate, presenting diffraction at 2 theta $=31^{\circ}$.

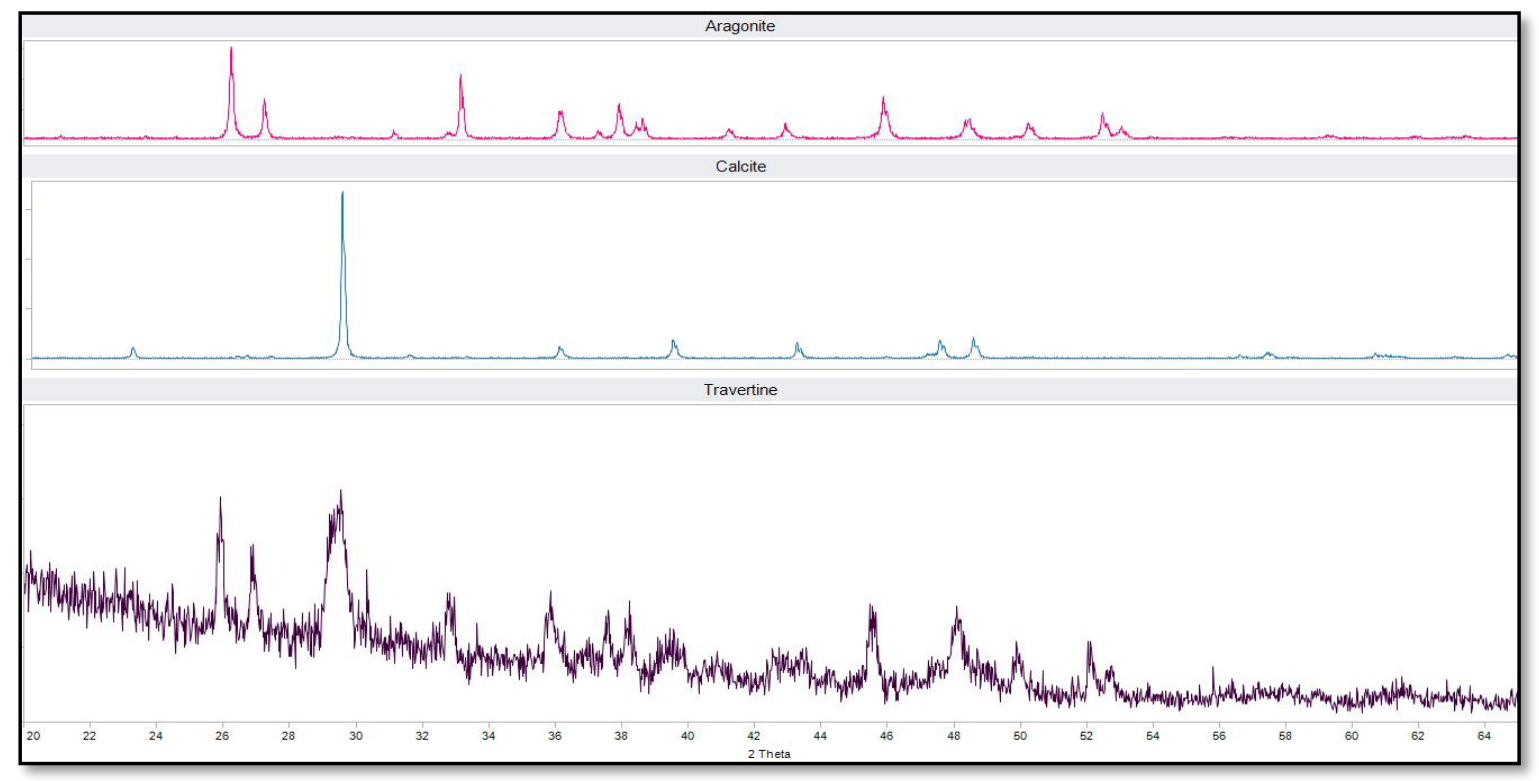

Figure 2 XRD travertine sample 


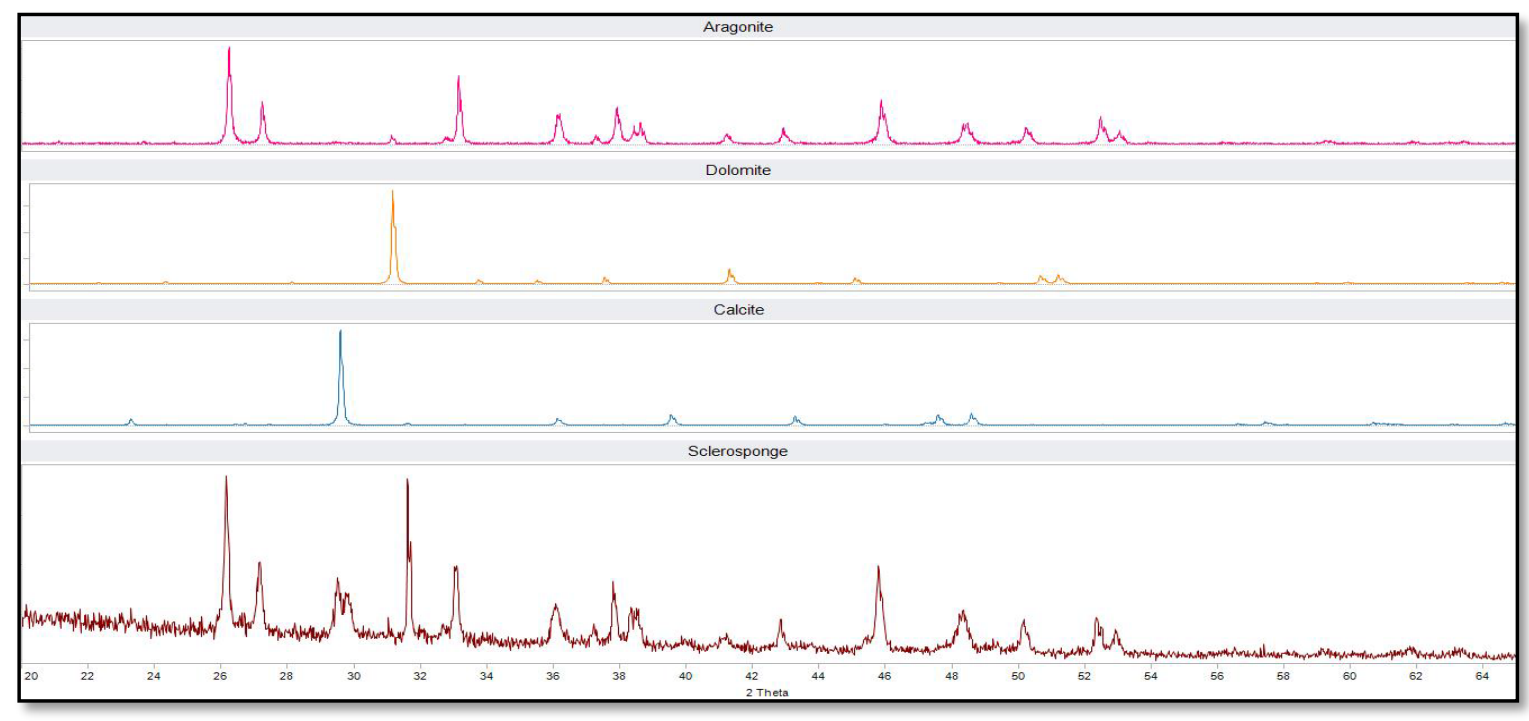

Figure 3 XRD sclerosponge sample

Appendix A. Table 1 Using peak intensities for quantitative analysis of diffraction usually refer to the determination of amounts of different phases in multi-phase samples (13).Using this analysis, it can be inferred that the Travertine sample contains approximately $76 \%$ of $\mathrm{CaCO}_{3}$ in aragonite form and 24\% in calcite form; on the other hand, the Sclerosponges rock analysis concludes that the sample contains approximately $66 \%$ of $\mathrm{CaCO}_{3}$ in Aragonite form, $15 \%$ in calcite form and $19 \%$ of its composition it is composed by dolomite $(\mathrm{CaMg})\left(\mathrm{CO}_{3}\right)_{2}$

\section{CERIUS 2 Simulation}

Using XRD patterns of each sample, molecular modeling calculations have been used to explore the different forms of crystallinity in travertine and sclerosponges rocks samples. The purpose using CERIUS 2 was to confirm the presence of the different crystal structures of calcium carbonate. The main phase that can be observed in both samples was aragonite. However, travertine and sclerosponges samples were also composed of other crystal phases (calcite and dolomite). 


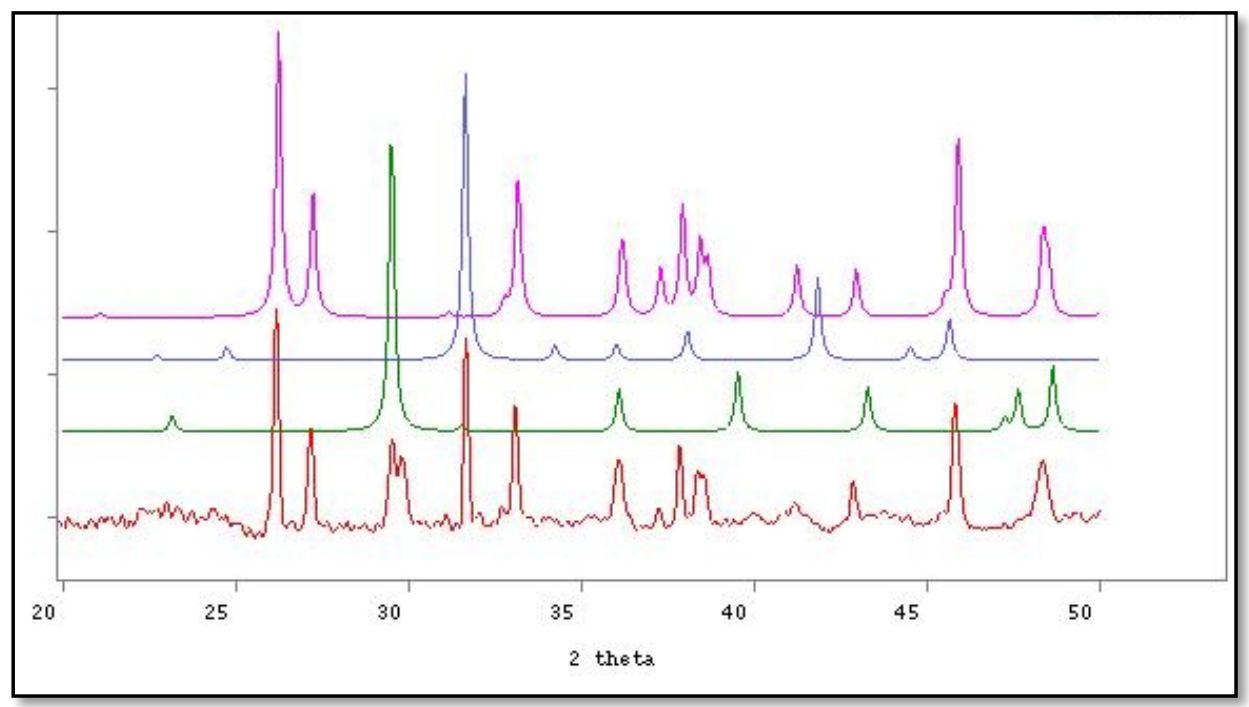

Figure 4 XRD CERIUS 2 simulation of sclerosponge sample

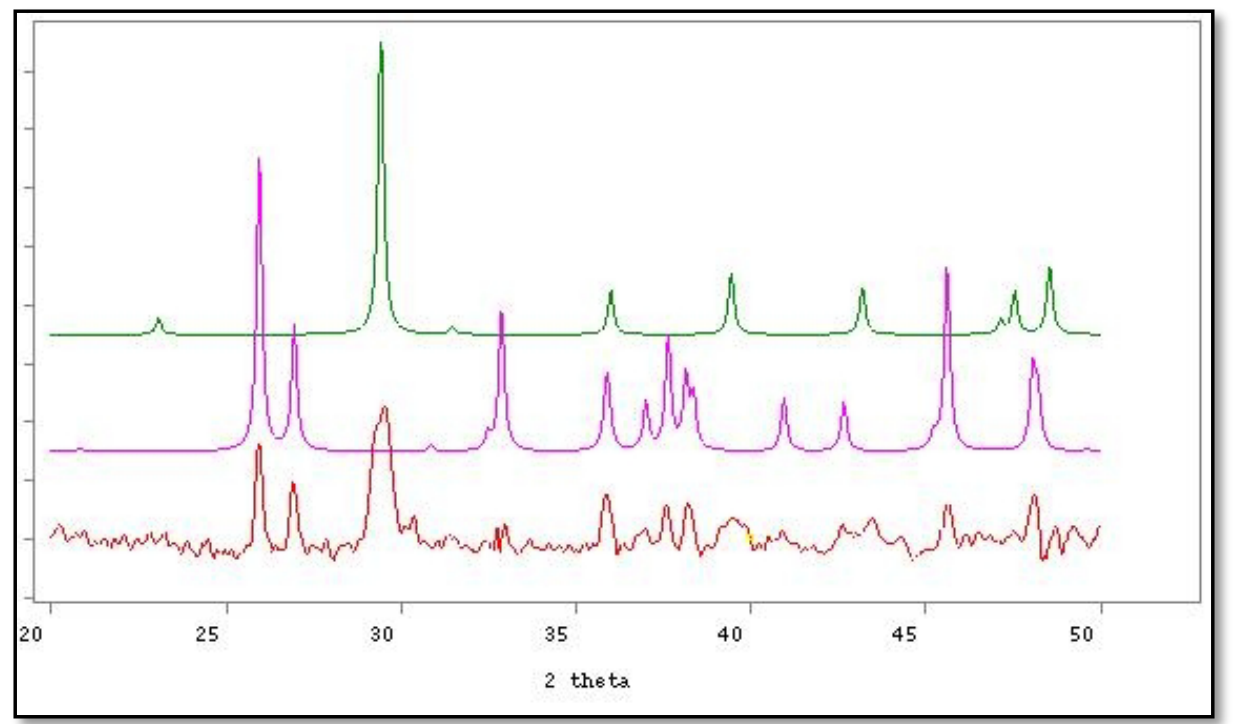

Figure 5 XRD CERIUS 2 simulation of travertine sample

According to CERIUS 2 Software confirms that calcite and aragonite crystal structures are present in both samples. In sclerosponge samples however, calcite and dolomite are also present but in lower amounts. 


\section{Fourier Transform Infrared Spectroscopy spectra (FTIR)}

FTIR spectroscopy is a useful tool in the molecular characterization of inorganic, organic species and crystalline or amorphous compounds. This vibrational technique, which is common in many analytical laboratories, also provides mineralogical information. Qualitative mineral identification is possible because minerals have characteristic absorption bands in the range of $4000-400 \mathrm{~cm}^{-1}$ (14) . The Infrared Spectra of these samples of the range of $400-4000 \mathrm{~cm}^{-1}$ with Smart Collector Sample Compartment (p/n 0031-999), PC, Omnic 6.1a software, Interpret IR Infrared Spectral Data Interpreter v2.0a software. The FTIR spectrum of Travertine sample Figure 6 consists in a mixture of calcite and aragonite, which show strong modes at 1444 and $855 \mathrm{~cm}^{-1}$ and a weak band at $712 \mathrm{~cm}^{-1}$ belonging to $\mathrm{CO}^{-2}$ anion (15)

Figure 7 shows the FTIR spectrum of Sclerosponge sample; this spectrum consists in a mixture of two polymorphs of calcium carbonate (calcite and aragonite) and Magnesium Carbonate (dolomite). Vibrational bands presented which the diagnostic ones are at 1483, 854 and $712 \mathrm{~cm}^{-1}$ belonging to $\mathrm{CO}_{3}{ }^{-2}$ anion, are slightly shifted from aforementioned bands due to the presence of dolomite, and apparently $\mathrm{Mg}$ causes an alteration in $\mathrm{CO}_{3}^{-2}$ ion bands presenting an overlapped with the bands of the aragonite which is according to XRD results, the predominant mineral(16, 17) . 


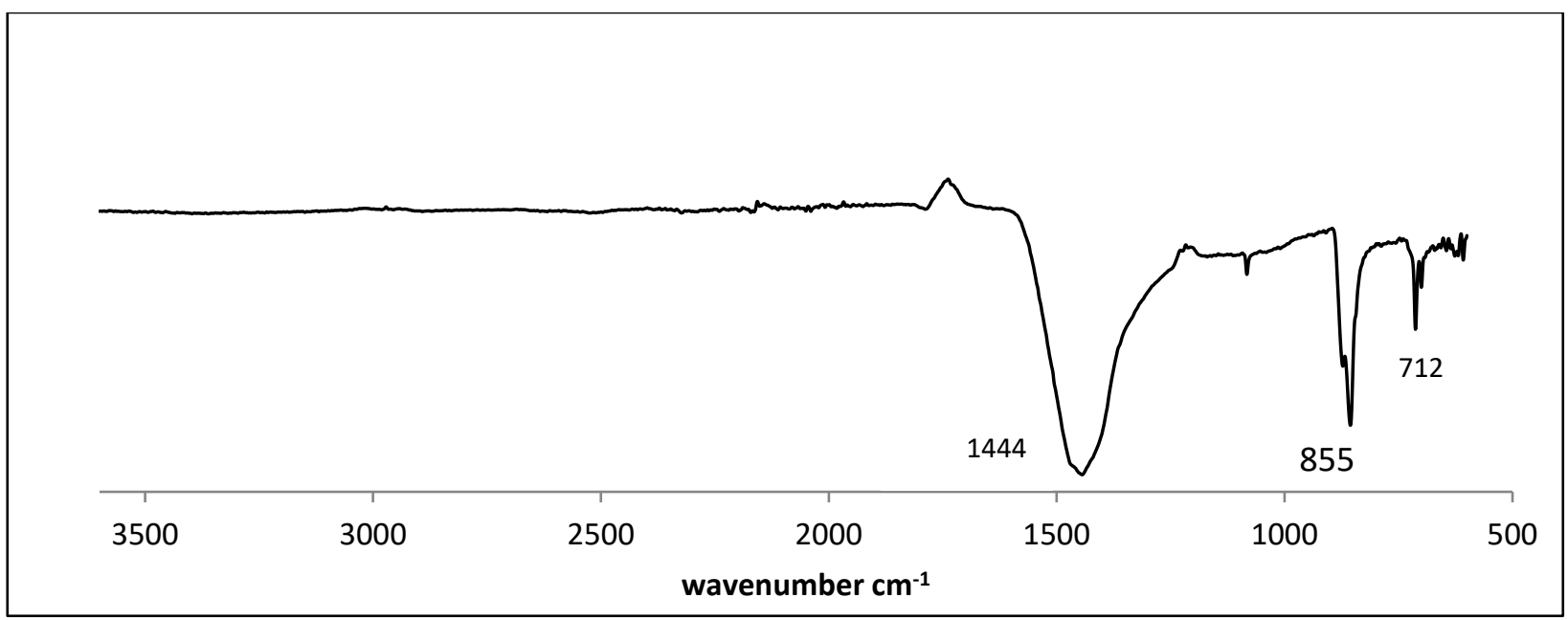

Figure 6 FTIR spectrum of travertine is a combination of the peaks found for calcite and aragonite polymorphs

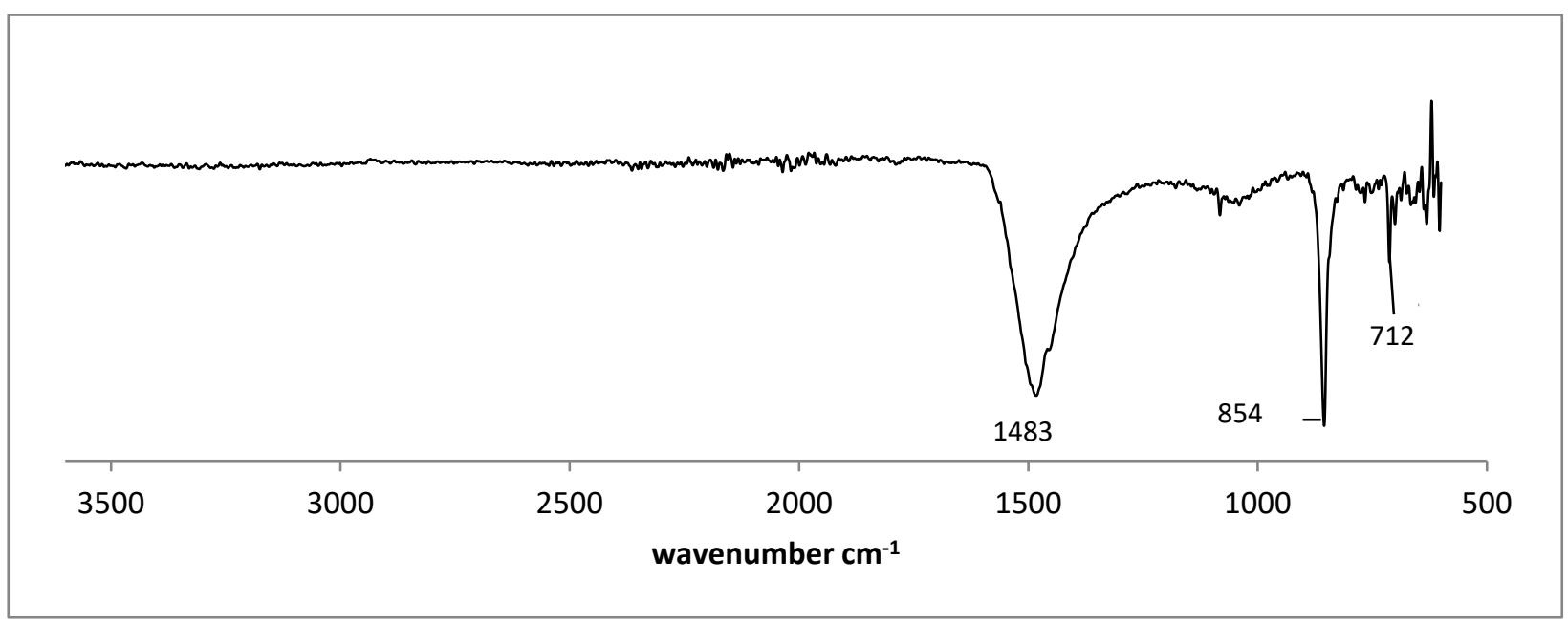

Figure 7 FTIR spectrum of sclerosponge sample is a combination of dolomite, calcite and aragonite minerals

\section{Stereoscopic microscope}

Observations with the stereoscopic microscope allowed the identification, with a low magnification, of the principal features that characterizes the stone alteration. Hand specimen examination was performed under the stereoscope (Olympus SZX12) The structure observed in travertine rock sample studied present different irregularly shaped pores with different morphologies, which are associated with coated bubbles, organism or plant casts (18) . In addition 
to these structures travertine rock is formed by two parts; a coral reef and mantle part which can be clearly observed in Figure 8. Two different areas are shown; the bottom part is the coral reef (white part) and the upper part is associated with the later deposition of Travertine (yellowish-brown part). The chemical composition of travertine is calcite and aragonite, the mantle is composed mainly of aragonite and the coral reef part is a mixture of calcite and aragonite, this is due to the later deposition of travertine and the rate of dissolution that occurred in the top of the coral reef.(3)

The Travertine crossed section Figure 9 showed a remarkable elliptical disc morphology which can be directly associated with a Coccolithophorids structure which are planktonic calcareous yellowgreen algae, because of their abundance and their preservation in sediments coccoliths are a valuable biostratigraphy marker of age and oceanic circulation.

Figure 10 shows the coral reef part found in Travertine, it can be observed that this area contains possible residue of plant and organism cast. Also, coccolith algae with star-shaped morphology discoasters were observed in the coral reef part. (8) 


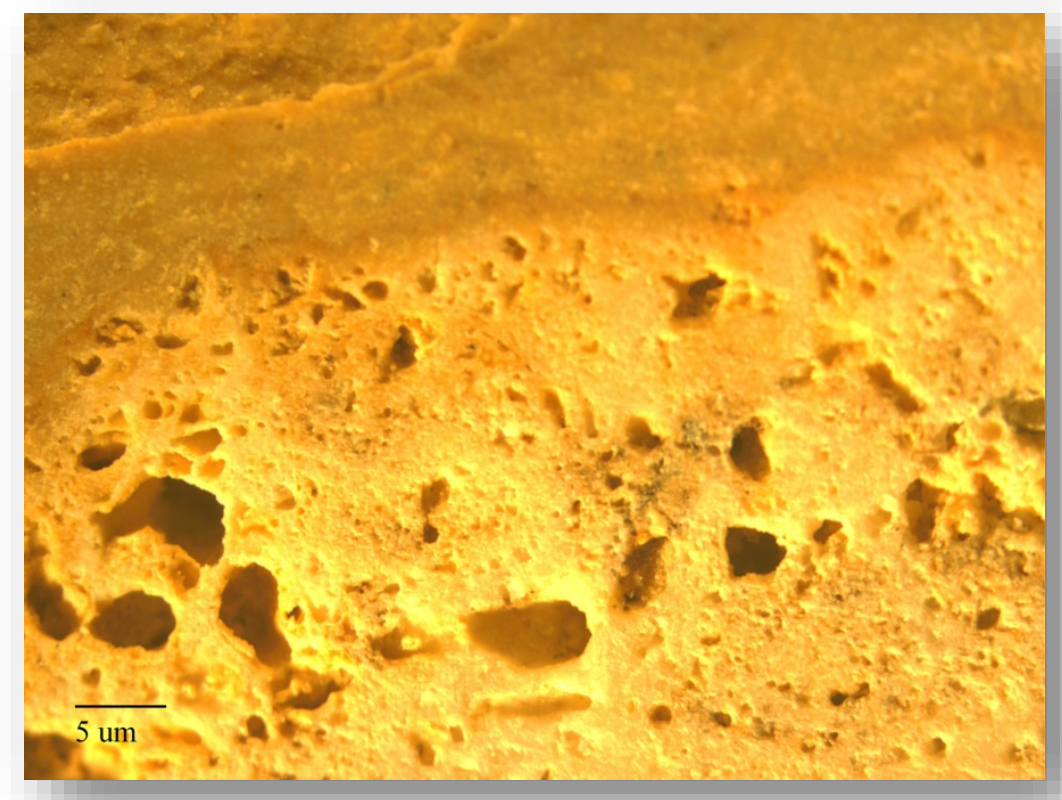

Figure 8 Rock sample, composed of coral reef (bottom part) and travertine (mantle) $7 \mathrm{X}$

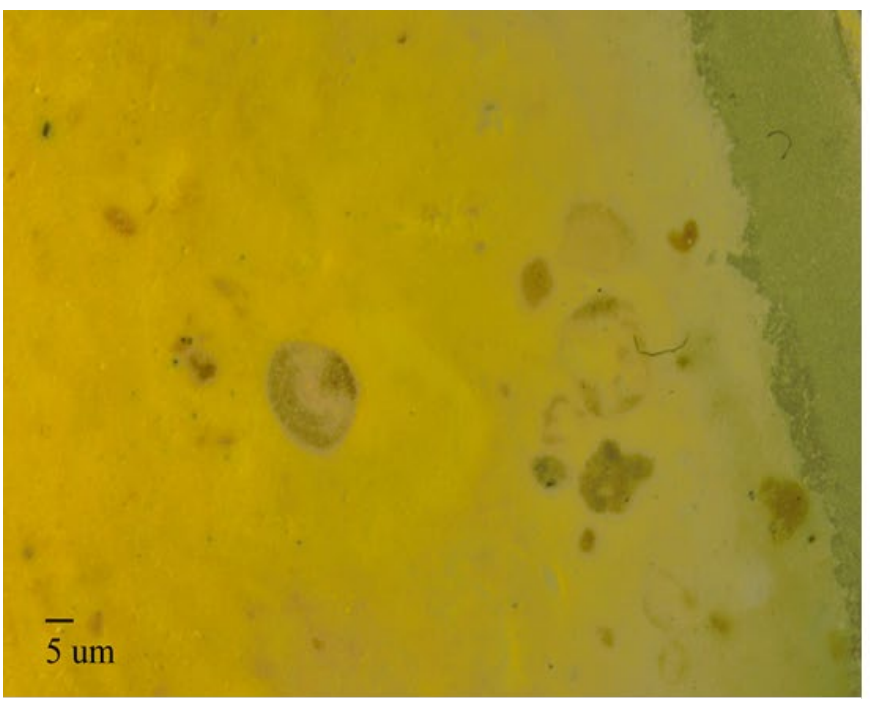
COCCOLITHS

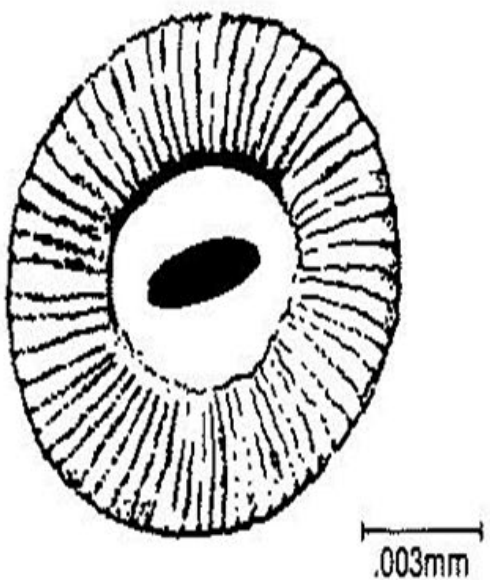

Figure 9 (left) Travertine cross-sectioned 32X resembles a coccolith structure (right). 32X Source: SPEM STRATA org 

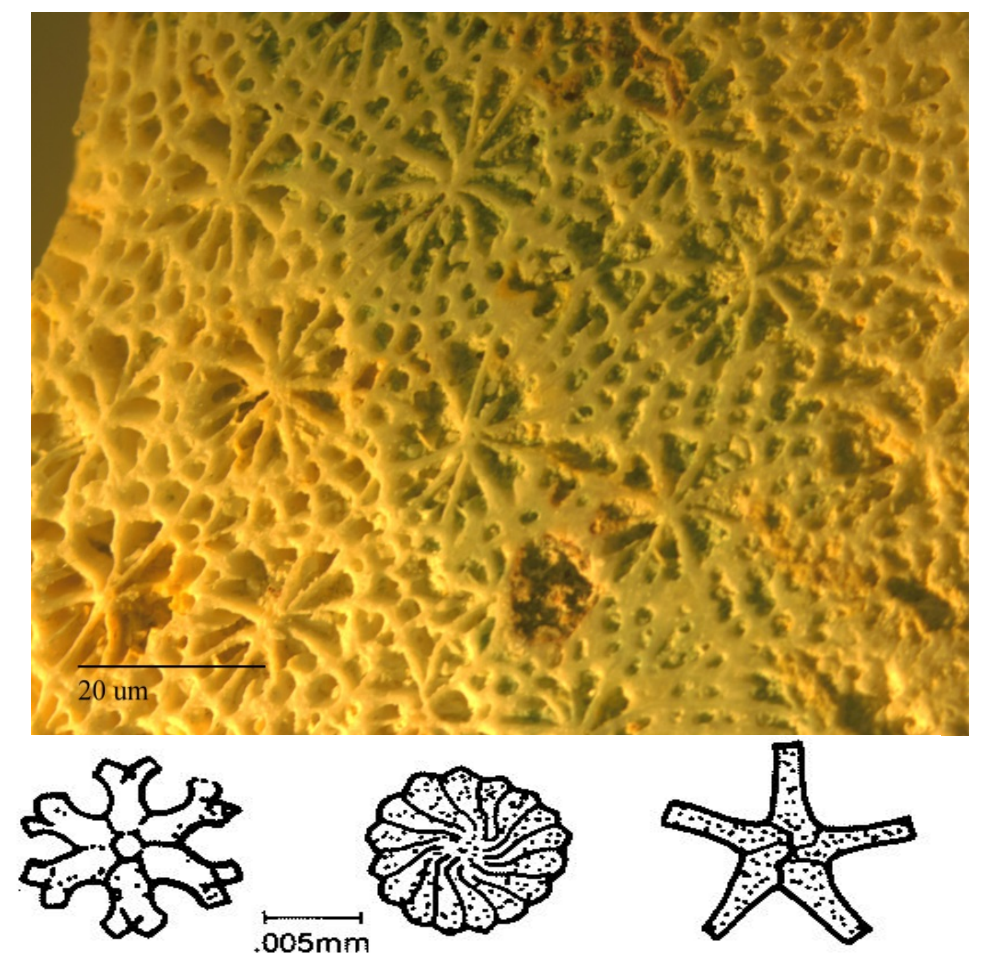

Figure 10 Star-shaped discoasters were observed at $12 \mathrm{X}$ using polarized light under the stereoscope this structure is just other morphology of the coccolith algae. Source: SPEM STRATA org

The skeleton of the sclerosponge sample appears as a solid homogeneous mass of calcium carbonate. The upper part of the rock's section Figure 11 is primarily composed of densely packed, branched canals together with spherical shaped cells like honeycomb (19). It is believed sclerosponges build their skeleton in a similar way scleractinian corals does, in which the porous upper portion of the skeleton houses the living organism (20). The following images clearly illustrate the fossil remains of an organism that attached to the surface of the rock; the organism's structure resembles those of the extinct stromatoporoid skeleton in their morphological growth patterns. Stromatoporoid casts consists of a tubular rigid "worm like" or domical and laminar like features that can be witnessed in the images below (8) . 

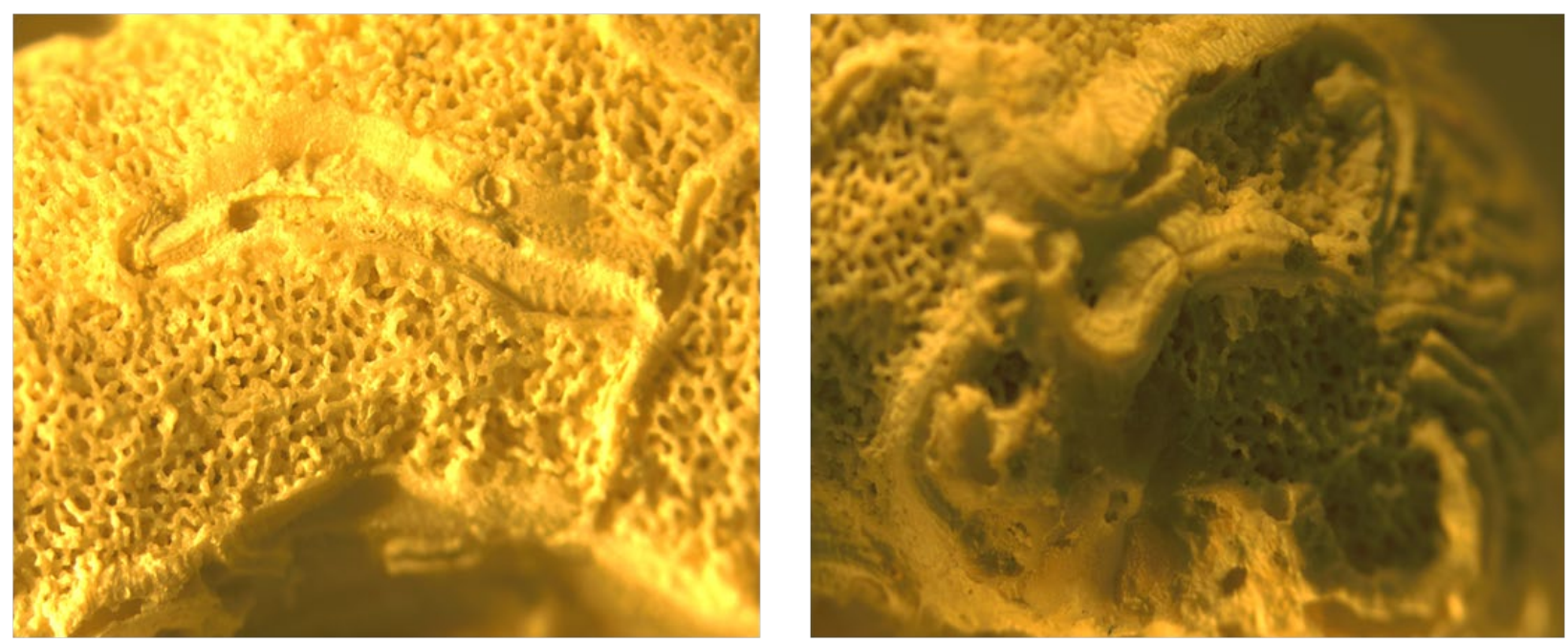

Figure 11 Fossil remains of an organism that attached to the surface of the rock; this organism may potentially be a stromatoporoid's cast

\section{Optical Microscopy}

Optical microscopy techniques are primarily analytical and descriptive tools for the petrographic analysis for all rock types (igneous, metamorphic and sedimentary). Observations using optical microscopy in transmitted and reflective light were used to analyze both samples to give primarily an analytical and descriptive interpretation for the sedimentary rock type. Optical microscopy techniques are used for studying mineral deposits and hydrothermal mineral alteration (21) . Sclerosponge transverse section Figure 12 also, suggest the presence of a Stromatoporoid skeleton, which resembles an overlapping dome-shaped structure or convex-inward plates with various supports or pillars which forms an irregular coarse structure (8). 


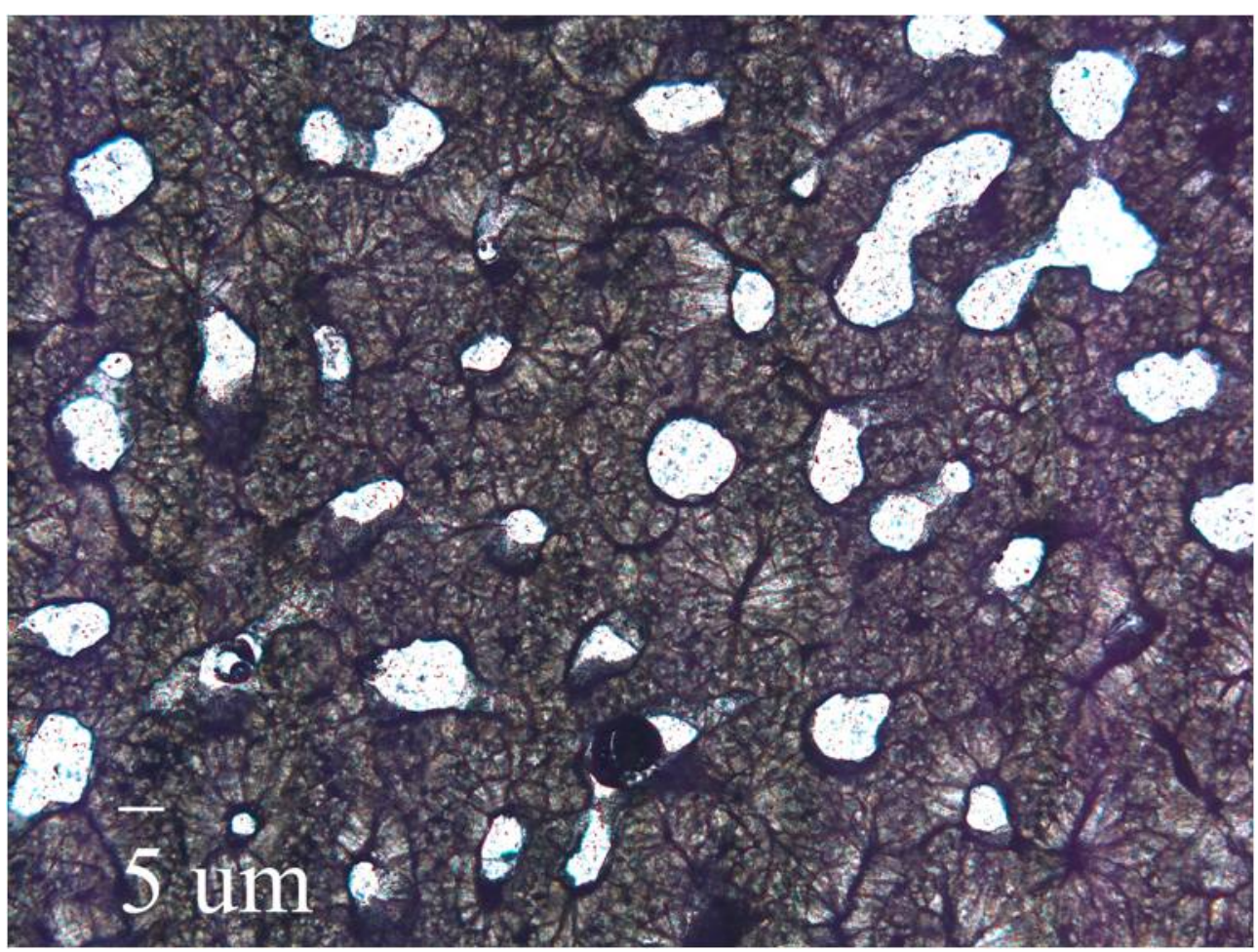

Figure 12 Thin-cross- section micrograph with transmitted light at 10X of Sclerosponge sample, the structure remains stromatoporoids structure with dome-shaped convex/inwards plates 
Figure 13 Travertine optical observations confirm the later deposition of aragonite crystals on top of calcite ones. Aragonite appears as a disordered opaque mass over the calcite crystals that are usually discolored aggregates layers. The aggregates are mainly concentrated in irregular, thin and dark laminae (22).
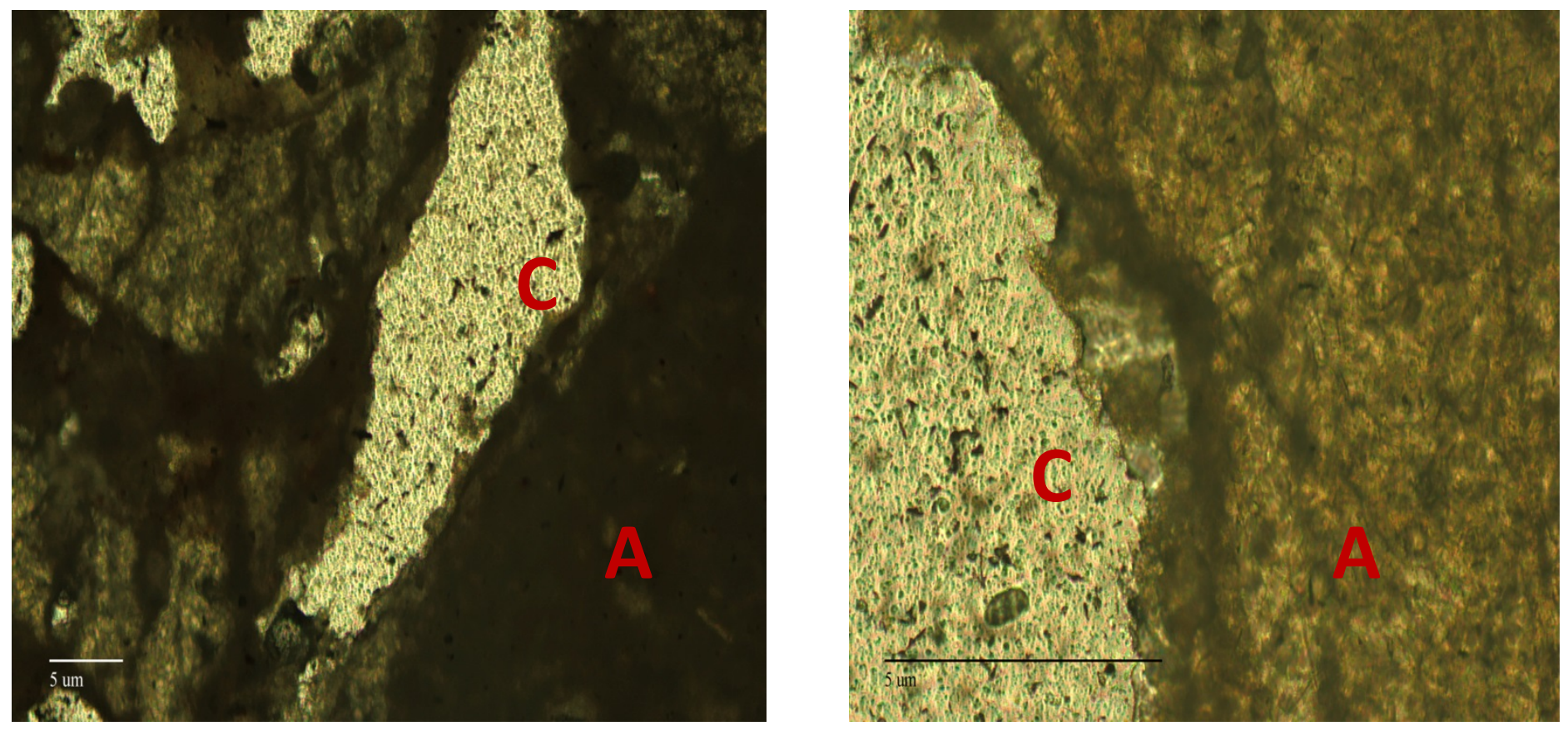

Figure 13 Thin cross-section micrograph toked with transmitted light at 5X (right) and 20X (left) of Travertine

\section{Data Analysis}

Previous research confirmed the cave was formed in a coral reef platform during emergence periods when sea level was lower than present days; then travertine formed a thin mantle over the coral reef substrate during a late period of emergence of the cave Aging results of $230 \mathrm{Th} / 234 \mathrm{U}$ for the travertine mantle are $90 \pm 5 \mathrm{k}$ a BP and the coral reef (bottom part of the rock) was found to date in the range of $130 \pm 8 \mathrm{k}$ a BP and $116+/-7 \mathrm{k}$ a BP; roughly 120,000 years old. These results are comparable with the period at which the coral reef platform was formed and also they are congruent with sea level records of Cebu throughout the late Pleistocene 
The sclerosponge specimens were initially formed on the ceiling of Marigondon Cave after it was submerged; they eventually dislodged and were buried in the silt. Duplicate $230 \mathrm{Th} / 234 \mathrm{U}$ testing of the sample provided calibrated ages of $2.24+/-0.08 \mathrm{k}$ a BP and $2.01+/-0.07 \mathrm{k}$ a BP; roughly 2000 years old.(3). According to Peterson 2013 this is comparable with the period of deposition of bulk sediments in a range from 570 to $1580 \mathrm{k}$ a BP and marine shell from 1720 to 1910k a BP analyzed by radiocarbon isotopes. Even though sclerosponge sample does not address the geological record of the cave, they do contribute a date for the cave floor, as it provides an agreement with the radiocarbon ages.

\section{Scanning Electron Microscopy (SEM)}

Structures of Travertine and Sclerosponges were observed in a Hitachi S-4800 field emission SEM operating at 20kV. The SEM was also fitted with an EDX energy-dispersive (x-ray) spectrometer (EDX). Travertine samples were coated with Au-Pd to minimize charging. The EDX analysis confirms the presence of calcium carbonate mineral as well as other minerals in lower amounts.

The microscopic imaging and spectral analyses of all layers showed that the chemical composition for both samples was calcium carbonate. Figure 14 (right) travertine micrograph showed rhombohedra crystals which structure is associated with calcite, however aragonite crystals were not clearly observed, even is the main phase presented in the sample, this could be explained because the actual shape of the crystal formed by organisms rarely looks like a perfect orthorhombic crystal structure and is more often elongated as needles, prisms or flattened as plates (23) .

Another possibility could be that Aragonite is thermodynamically unstable at standard temperature and pressure and tends to alter to calcite. EDX analyses of the mineral phases naturally showed $\mathrm{Ca}$, 
$\mathrm{C}$ and $\mathrm{O}$ as peaks for the carbonate substrate. In addition, $\mathrm{Mg}$ peaks were observed in the Sclerosponge sample micrographs

Calcified filaments are the most common biogenic components of organism coverings. The detailed studies of all layers in Travertine locate a morphology structure of a calcifying organism. Well-developed calcified filaments tend to keep the original shape with a central circular hole filled or empty Figure 14(left).Research on the field has demonstrated that the morphology of the filaments is conserved by the encrustation of calcite on the covers of the filaments and a tube is left when the organic matter decays. (24)

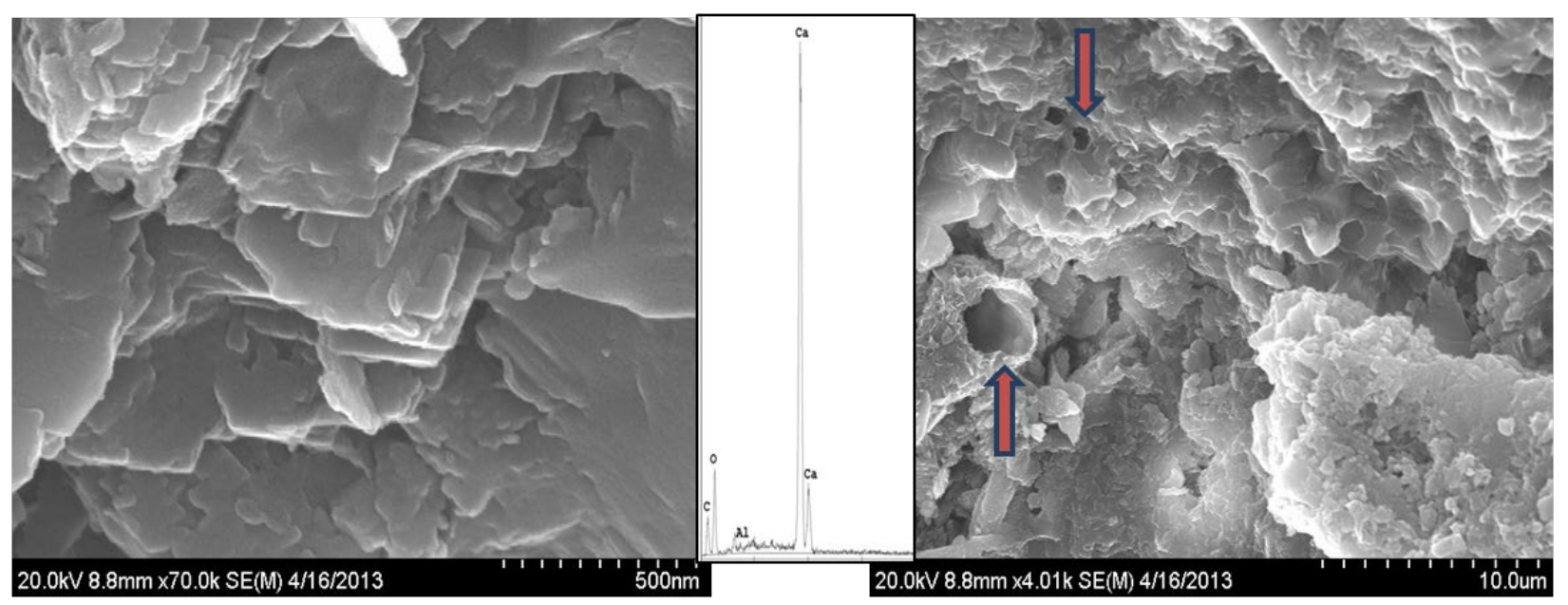

Figure 14 (left) SEM micrographs of Travertine showing a typically rhombohedra crystal structure of calcite (right) Calcified filaments associated with bacteria were found in one of the travertine layers. EDX image attached showing the mineralogy chemical composition for travertine

Sclerosponges micrographs showed randomly arranged crystals with a center of calcification, crystals started to grow in length away from their center of calcifications, as these proceeds the crystals become associated in groups which form prism like structure. Figure 15 showed zones of 
larger oriented crystals as other with different orientation of the center of calcification this growth process is likely associated with the growth and calcification of coral skeletons(25) .

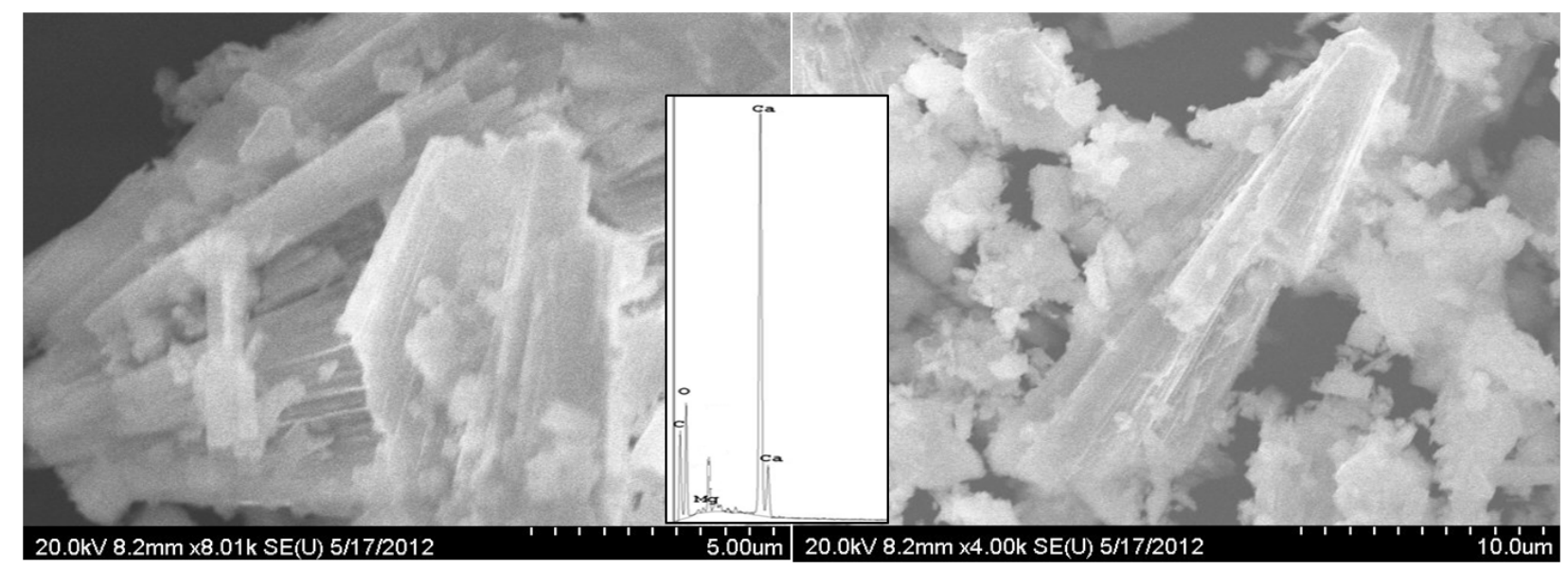

Figure 15 SEM micrographs of sclerosponge sample showing calcium carbonate crystals with a prism structure found in one of the sample layers. EDX image attached showing the mineralogy chemical composition for Sclerosponge

\section{Conclusion}

The undeniable presence of different minerals such as aragonite and calcite were confirmed by X-Ray diffraction and FTIR analysis in both samples travertine and sclerosponges. In addition, the presence of dolomite in Sclerosponge material was also observed by XRD, FTIR, and Energy dispersive X-ray spectroscopy techniques. Petrography analysis in sclerosponges sample have shown an organism cast which could resembles a stromatoporoid's cast, these organisms were important reef formers in the Paleozoic era, however $230 \mathrm{Th} / 234 \mathrm{U}$ aging data $(2,000$ years $)$ clarifies that this sediment contains an evolved form of these organisms (7).Cross-sections of travertine specimens showed a remarkable elliptical disc morphology which can be directly associated with a Coccolithophorids. Both analyses confirm that the formation of the rock samples was due to biomineralization assisted by organisms as well as mineral deposition. This is supported by the identification of calcite and aragonite phases of crystallization in the different 
samples; which demonstrates the formation of the coral fossils was through a process including mineral deposited by photosynthesis, as well as, trapping of sediment. Calcite frequently observed in biominerals is the most stable phase of calcium carbonate in aqueous solutions. In other organisms a metastable phase of $\mathrm{CaCO}_{3}$ exists as Aragonite, interestingly the precipitated aragonite can be stabilized in living systems (26); this is an important contribution since this can be a key that the strata collected have a potential wide area of unexplored paleoenviromental data.

Travertine mantle formed over the old coral reef platform. Dating analysis confirms the later deposition of the mantle when the cave was formed. Results yields $90 \pm 5 \mathrm{k}$ a BP for the travertine mantle and $130 \pm 8 \mathrm{k}$ a BP in the coral reef part of the specimen, which also is congruent with the formation of the coral reef platform during subaerial periods when the sea level was lower than today. The analysis in this paper supports that these samples formed during periods of submergence and emergence of the cave.

Marigondon Cave would have been above water and favorable for Pleistocene fauna as well as possibly human settlement. In this context, the cave provides opportunities for discovery of fossil assemblages that may be preserved in terrestrial deposits in the caves.

\section{Acknowledgments}

This research paper would not have been possible without the support of many people. The authors wish to express gratitude to Geology department of The University of Texas at El Paso especially to Ramon who was abundantly helpful and offered invaluable assistance, support and guidance. Deepest gratitude also due to the members of the Materials Research and Technology Institute: Brenda Torres, Maryam Zarei, Belinda Molina, Mahsa Hosseini and Joaquin Rodriguez, without whose knowledge and assistance, this study would not have been successful. With a 
special thanks also to group members; Dr. John Peterson, Dr. Lin Ma and Dr. Russell Chianelli for sharing the literature and invaluable assistance. The authors would also like to convey thanks to the University of Texas at El Paso for providing all the facilities needed. 


\section{Appendix A Table 1}

\begin{tabular}{|c|c|c|c|c|c|}
\hline \multicolumn{6}{|c|}{ Sclerosponges } \\
\hline 2 theta & theta & sin theta & d & phase & plane \\
\hline 26.56 & 13.28 & 0.23 & 3.35 & aragonite & 111 \\
\hline 27.30 & 13.65 & 0.24 & 3.26 & aragonite & 102 \\
\hline 33.50 & 16.75 & 0.29 & 2.67 & aragonite & 201 \\
\hline 36.30 & 18.15 & 0.31 & 2.47 & aragonite & 020 \\
\hline 37.30 & 18.65 & 0.32 & 2.41 & aragonite & -210 \\
\hline 38.30 & 19.15 & 0.33 & 2.35 & aragonite & $0-13$ \\
\hline 45.80 & 22.90 & 0.39 & 1.98 & aragonite & $1-22$ \\
\hline 48.30 & 24.15 & 0.40 & 1.91 & aragonite & -104 \\
\hline 30.00 & 15.00 & 0.26 & 2.98 & calcite & 104 \\
\hline 40.00 & 20.00 & 0.34 & 2.25 & dolomite & 113 \\
\hline 49.20 & 24.60 & 0.42 & 1.85 & dolomite & 116 \\
\hline \multicolumn{6}{|c|}{ Travertine } \\
\hline 2 theta & theta & sin theta & $d$ & phase & plane \\
\hline 26.30 & 13.15 & 0.23 & 3.38 & aragonite & 111 \\
\hline 27.00 & 13.50 & 0.23 & 3.30 & aragonite & 021 \\
\hline 33.00 & 16.50 & 0.28 & 2.71 & aragonite & 012 \\
\hline 38.60 & 19.30 & 0.33 & 2.33 & aragonite & 130 \\
\hline 42.60 & 21.30 & 0.36 & 2.12 & aragonite & 220 \\
\hline 47.20 & 23.60 & 0.40 & 1.93 & aragonite & 221 \\
\hline 48.60 & 24.30 & 0.41 & 1.87 & aragonite & 202 \\
\hline 50.80 & 25.40 & 0.43 & 1.80 & aragonite & 132 \\
\hline 53.00 & 26.50 & 0.45 & 1.73 & aragonite & 231 \\
\hline 29.40 & 14.70 & 0.25 & 3.03 & calcite & 104 \\
\hline 36.30 & 18.15 & 0.31 & 2.47 & calcite & 110 \\
\hline
\end{tabular}

\section{Table 1 Diffraction patterns}




\section{References}

1. P. J. van Hengstum, D. B. Scott, D. R. Gröcke, M. A. Charette, Sea level controls sedimentation and environments in coastal caves and sinkholes. Mar. Geol. 286, 35-50 (2011).

2. G. N. Bailey, N. C. Flemming, Archaeology of the continental shelf: Marine resources, submerged landscapes and underwater archaeology. Quaternary Science Reviews. 27, 2153-2165 (2008).

3. J. Peterson, A. Jalandoni, C. Rocha, An archaeological survey of an underwater cave in Marigondon, Philippines. (2013).

4. E. Raeisi, J. E. Mylroie, Hydrodynamic behavior of caves formed in the fresh-water lens of carbonate islands. Carbonates and Evaporites. 10, 207-214 (1995).

5. E. Anzalone, V. Ferreri, M. Sprovieri, B. D'Argenio, Travertines as hydrologic archives: The case of the Pontecagnano deposits (southern Italy). Adv. Water Resour. 30, 2159-2175 (2007).

6. G. M. Gadd, Metals, minerals and microbes: geomicrobiology and bioremediation.

Microbiology. 156, 609-643 (2010).

7. L. L. Basile, R. J. Cuffey, D. F. Kosich, Sclerosponges, Pharetronids, and Sphinctozoans (Relict Cryptic Hard-Bodied Porifera) in the Modern Reefs of Enewetak Atoll. J. Paleontol. 58, 636-650 (1984).

8. SPEM, Strata, Society for Sedimentary Geology, Skeletal Grains. SPEM Strata. 2013 (2013).

9. L. Hinderstein, C. Wood, Shocking Tell-All: Sclerosponges Reveal Secrets of Past Climate. Feb, 2013, 1 .

10. J. A. Peterson, Two shoreline terraces and their possible implications for coastal adaptation in the late Iron age of Cebu, Philippines. Philippine Quarterly of Culture and Society. 33, 127-154 (2005).

11. L. Batoon, L. Gay., "Marigondon Underwater Cave, Marigondon, Mactan, Cebu," Report to the National Museum of the Philippines, 2005).

12. E. Flügel, Microfacies of carbonate rocks: analysis, interpretation and application (Springer Verlag, , 2004).

13. J. R. Connolly, Introduction Quantitative X-Ray Diffraction Methods. (2010).

14. J. Ji, Y. Ge, W. Balsam, J. E. Damuth, J. Chen, Rapid identification of dolomite using a Fourier Transform Infrared Spectrophotometer (FTIR): A fast method for identifying Heinrich events in IODP Site U1308. Mar. Geol. 258, 60-68 (2009). 
15. Buzgar, Nicolae., Ionut- Apopoei, Andrei, The Raman Study of Certain Carbonates. University of Iaşi, Department of Geology (Romania).(2009).

16. A. Elisabet Lavat, M. Cristina Grasselli, Phase evolution during preparation of spinelcontaining refractory cements, from argentine dolomite. ADVANCES IN TECHNOLOGY OF MATERIALS AND MATERIALS PROCESSING JOURNAL. 9, 103 (2007).

17. K. D. O. Jackson, A Guide to Identifying Common Inorganic Fillers and activators using Vibrational Spectroscopy. (2004).

18. M. Á García-del-Cura, D. Benavente, J. Martínez-Martínez, N. Cueto, Sedimentary structures and physical properties of travertine and carbonate tufa building stone. Constr. Build. Mater. 28, 456-467 (2012).

19. K. Mori, A calcitic sclerosponge from the Ishigaki-shima Coast, Ryukyu Islands, Japan. 47(1977).

20. S. Elias, C. Mock, Encyclopedia of Quaternary Science (Elsevier Science, , 2013).

21. A. Milodowski, Optical petrography and ore microscope. British Geology Survey. 2013(2013).

22. L. Guo, R. Riding, Aragonite laminae in hot water travertine crusts, Rapolano Terme, Italy. 39(2006).

23. W. Goldberg, Biology of Corals. 2013.

24. J. Zhou, H. S. Chafetz, Biogenic caliches in Texas: The role of organisms and effect of climate. (2009).

25. S. A. Wainwright, Studies of the mineral phase of coral skeleton. Exp. Cell Res. 34, 213-230 (1964).

26. R. Liu et al., Preparation of Calcite and Aragonite Complex Layer Materials Inspired from Biomineralization. Crystal Growth \& Design. 9, 3095-3099 (2009). 